\title{
THE INUESTIGATION OF PRODUCTIVE AND RECEPTIVE COMPETENGE IN U+N AND ADJ+N COLLOCATIONS AMONG INDONESIAN EFL LEARNERS
}

\author{
Saudin \\ lis Sulyaningsih \\ Lina Meilinda \\ Politeknik Negeri Bandung \\ saudin@polban.ac.id; iis.sulyaningsih@polban.ac.id; lina.meilinda@polban.ac.id
}

First received: 27 Februari 2017

Final Proof Received: 29 May 2017

\begin{abstract}
The important role of collocation in learners' language proficiency has been acknowledged widely. In Systemic Functional Linguistics (SFL), collocation is known as one prominent member of the super-ordinate lexical cohesion, which contributes significantly to the textual coherence, together with grammatical cohesion and structural cohesion (Halliday \& Hasan, 1985). Collocation is also viewed as the hallmark of truly advanced English learners since the higher the learners' proficiency is, the more they tend to use collocation (Bazzaz \& Samad, 2011; Hsu, 2007; Zhang, 1993). Further, knowledge of collocation is regarded as part of the native speakers' communicative competence (Bazzaz \& Samad, 2011); and lack of the knowledge is the most important sign of foreignness among foreign language learners (McArthur, 1992; McCarthy, 1990). Taking the importance of collocation into account, this study is aimed to shed light on Indonesian EFL learners' levels of collocational competence. In the study, the collocational competence is restricted to $\mathrm{v}+\mathrm{n}$ and $\mathrm{adj}+\mathrm{n}$ of collocation but broken down into productive and receptive competence, about which little work has been done (Henriksen, 2013). For this purpose, 49 second-year students of an English department in a state polytechnic were chosen as the subjects. Two sets of tests (filling in the blanks and multiple-choice) were administered to obtain the data of the subjects' levels of productive and receptive competence and to gain information of which type was more problematic for the learners. The test instruments were designed by referring to Brashi's (2006) test model, and Koya's (2003). In the analysis of the data, interpretive-qualitative method was used primarily to obtain broad explanatory information. The data analysis showed that the scores of productive competence were lower than those of receptive competence in both $\mathrm{v}+\mathrm{n}$ and $\mathrm{adj}+\mathrm{n}$ collocation. The analysis also revealed that the scores of productive and receptive competence in $\mathrm{v}+\mathrm{n}$ collocation were higher than those of productive and receptive competence in adj $+n$ collocation. The finding comes as a surprise since it turns out adj $+n$ collocation is more problematic than $\mathrm{v}+\mathrm{n}$ collocation both productively and receptively. Much research, by contrast, has reported that mistakes in $\mathrm{v}+\mathrm{n}$ collocation are typical (Al-Zahrani, 1998; Nesselhauf, 2003; Liu, 1999; Sun, 2004). A conclusion has even been drawn that " $\mathrm{v}+\mathrm{n}$ collocation is more difficult than adj+n collocation" (Kuo, 2009, p. 148). Though more studies are needed to support its finding, this research suggests the type of collocation deserve to get more attention from researchers.
\end{abstract}

Keywords: SFL; EFL; cohesion; coherence; collocation; productive and receptive competence

The term collocation was coined by Palmer (1933) and brought to the field of linguistics by Firth (1957). The term has its roots in a Latin verb 'collocare' which means 'to set in order/to arrange' (Hsu, 2007; Mahvelati \& Mukundan, 2012). Lewis (2000, p. 74 in Miyakoshi, 2009) defined collocation as "two or more words that tend to cooccur together." Martin (1992) simply referred to collocation as mutual expectancy between lexical items. Halliday \& Matthiessen (2004) termed collocation as the co-occurrence tendency of associative lexical items. In this study, collocation (e.g. make mistakes, go bankrupt or heavy traffic) is viewed as a lexical combination that sounds natural to native speakers and has high predictability since the word constituents often appear in the same lexical environment.

In Systemic Functional Linguistics (SFL), collocation is the main part of lexical cohesion, one major category of (textual) cohesion, that is, an internal unity of a text formed when one element of a text is dependent for its interpretation on another (Halliday \& Hasan, 1976; Eggins, 2004). Collocation contributes to lexical cohesion by providing semantic ties among words. It is said that in a corpus study of a spoken genre, cohesion is largely lexical at 70\% (Taboada, 2004, p. 170).

The importance of collocation in language learning is acknowledged widely in the theories of second language acquisition (Anari \& Ghaffarof, 2013). Bazzaz \& Samad (2011), Hsu (2007) and 
Saudin (2014) proved in their studies that learners tend to use more collocations at more advanced levels. That means the uses of well-formed collocation indicate the development of learners' language learning and frequent failures in realizing well-formed collocations are important signs of learners' low English proficiency. It also was reported that competence in using collocation is a source of fluency in a specific skill such as writing (Hsu, 2007; Zhang, 1993) and speaking (Sung, 2003). Some other researchers (Al-Zahrani, 1998; Bonk, 2000) showed a positive relation between the collocational competence and learners' general English proficiency as reflected by their TOEFL and TOEIC scores. Anari \& Ghaffarof (2013) just recently revealed a significant correlation between collocational competence and translation accuracy.

To show the crucial position of collocation in the second language acquisition, other researchers have conducted research on various aspects of collocation. Bahns \& Eldaw (1993) and Zughoul \& Abdul-Fattah (2003) investigated collocational competence among EFL/ESL learners. Other researchers (Kuo, 2009; Yan, 2010) analyzed EFL/ESL students' mistakes in forming collocation. Some others such as Ellis (2001) and Nation (2001) reported some evidences that collocation was a crucial part of language use and that collocation competence distinguished native and non-native speakers.

Despite a large number of studies on collocation having been done, deeper studies on collocation competence (which is divided into productive and receptive types) are still limited (Henriksen, 2013). To the best of the present researchers' knowledge, there have been just two studies (Brashi, 2006 and Koya, 2003) investigating these two kinds of collocational competence. Brashi (2006) analyzed EFL/ESL Arabian learners' levels of productive and receptice collocational competence. Koya (2003) studied the relationship between the development of productive-receptive knowledge of collocation and the development of vocabulary in general, the ways of some learners of different levels of proficiency acquiring the two types of collocational knowledge, and the roles of the two types of collocational knowledge or competence in successful communication.

The present study is similar to Brashi's (2006) and Koya's (2003) in that it investigated the two types of collocational competence: productive and receptive. To divide collocational competence into these two types is necessary. The division can inform more accurately the level of learners' collocational competence. Besides, the division can give valuable suggestions on how teaching practitioners design their pedagogical practices to help the learners overcome their difficulty in acquiring collocation. As reported by many studies (Anari \& Ghaffarof, 2013), collocation is difficult for the learners to learn and use.

However, this study is different from Brashi's (2006) and Koya's (2003) in two respects. The first difference is that their studies just focused on one type of collocation, that is, $v+n$ collocation, while this study investigated two types of collocation, namely $v+n$ and adj $+n$ collocation. It is said that the two types are the mostly used and the mostly mistakenly realized in learners' texts regardless of their levels of proficiency (Siyanova \& Schmitt, 2008; Yan, 2010). The second difference is that Brashi's (2006) and Koya's (2003) studies accordingly did not discuss which of the two types of collocations was more problematic for learners as this study did. As such, this study contributed more points to the research subject of collocation.

To explicitly state its purposes, the study aimed to reveal the levels of productive and receptive knowledge of $v+n$ and adj $+n$ collocations among some Indonesian EFL learners. Besides, the study attempted to show whether $v+n$ collocation or $\operatorname{adj}+n$ collocation was more difficult for the learners, who were undergraduate students of English Language Department of Bandung State Polytechnic.

\section{Collocation}

Benson et al. (1997 in Mahvelati \& Mukundan, 2012) divided collocation into two major categories: lexical collocation and gramatical collocation. Lexical collocation is a syntagmatic combinations of content words (nouns, verbs, adjectives and adverbs) such as draw a conclusion $(\mathrm{v}+\mathrm{n})$ or heavy traffic $(\operatorname{adj}+n)$. Grammatical collocation, on the other hand, is a word combination between a content word (a noun, verb or adjective) and a function/grammatical word (a preposition or particle), for example argument about $(\mathrm{n}+\mathrm{prep})$, by accident (prep+n), depend on ( + prep) and interested in (adj+prep). Grammatical collocation also includes combinations between a content word (a noun or an adjective) and a grammatical structure (to infinitive or that-clause).

In The BBI dictionary of English word combinations, Benson et al. (1997) proposed seven sub-types of lexical collocation and eight sub-types of grammatical collocation. Along with the theoretical development of collocation, it seems that the sub-types of grammatical collocation get less in number. This is due to researchers' lack of attention to research on combinations between a noun or an adjective and to infinitive or that-clause. Mahvelati \& Mukundan (2012), Saudin (2014) and Yan (2010), listed the examples of the two sub-types syntagmatically as follows: 
- Lexical Collocations

(1) $\mathrm{v}+\mathrm{n}$ : make mistakes, do business and take advantage of.

(2) adj $+\mathrm{n}$ : strong tea/wind, powerful machine, heavy rain, and fast train.

(3) $n+n$ : traffic accident, human resources and communication breakdown.

(4) v+adv: laugh merrily, appear suddenly, rain heavily, and argue heatedly.

(5) adv + adj: strikingly different, absolutely right and truly mad.

(6) $\mathrm{v}+$ adj (linking verb collocation): turn grey, go blind, and keep clean.

(7) $\mathrm{n}+\mathrm{v}$ : bees buzz, doctors diagnose, a baby cries, and a dog barks.

(8) $n+$ adj: crystal clear, pitch black, emerald green, and paper thin.

- Grammatical Collocations

(1) prep+n: in agony/despair, at speed, on $t v$, on purpose and out of position.

(2) n + prep: attack on, error/increase in, and need/preference/love for.

(3) v + prep (phrasal verbs collocation): rely on, dry up, and look after.

(4) adj + prep: dependent on, familiar with, close to and angry with.

(5) quantifier $+\mathrm{n}$ : a pride of lions, a bar of chocolate and a drop of water.

(6) prep+prep: back to, out of, apart from, and from-to.

The examples of collocation above may hint that collocation is characterized by merely its syntagmatic lexical combination. It is not completely true. Some researchers (Howarth 1998; Miyakoshi, 2009) suggest that only when do syntagmatic lexical combinations have certain properties, they belong to collocations. Three are considered to be common properties of collocation: restrictedness, semantic transparency and particular position which is situated between idioms on one end and free combinations on the other.

Such word combinations as break the news or break the promise are restricted - thus regarded as collocation because the constituent break cannot be replaced by a similar word such as inform or violate to form *inform the news or *violate the promise. Furthermore, the collocations break the news and break the promise above have word constituents which are still transparent in their meanings. The meanings of the two collocations can still be deduced from those of the lexical items which compose the collocations.

In relationship with a free word combination and an idiom, collocation is in between them. Collocations such as the two examples above are different from the combinations of break and lexical items like glasses, a vase, the windows and many other nominal groups, which are relatively limitless. They are just called free word combinations, "just combinations of words following only the general rules of syntax: the elements are not bound specifically to each other and they can be substituted with other lexical items freely" (Miyakoshi, 2009, p. 5). Also, the two above-mentioned collocations are different from the meaning of an idiom (e.g. break a leg, used to wish somebody good luck), which is non-compositional. That means the meaning of an idiom cannot be inferred from that of its individual words. Hence, collocation is placed in a continuum between idioms on one end and free word combinations on the other although "the boundaries between idioms, collocations and free combinations are not clear-cut" (Miyakoshi, 2009, p. 6).

This study tried to differentiate more explicitly between idioms and free word combinations on one hand and collocation on the other. For the purpose, the choices of collocation used in the study was checked against Oxford Collocations Dictionary (McIntosh, 2009). In addition, online data sources such as British National Corpus (BNC) were referred to. BNC, which is a huge data base of authentic texts, stores much information about how words and phrases are used in sentences. When words often co-occur in one lexical environment in $\mathrm{BNC}$, this proves that the combinations are wellformed collocations (Kuo, 2009).

\section{Collocational Competence}

Collocational competence is an important aspect of native speakers' communicative competence, involving knowledge to know which words usually come together and which do not (Bazzaz \& Samad, 2011). It is also said that collocational competence is important knowledge for language production and reception that enables both the L1 and L2 language user to make idiomatic choices and come across as native-like (Henriksen, 2013). Some linguists (Alsakran, 2011; Brashi, 2006) categorize collocational competence into productive and receptive type. The categorization is informed by Nation's (2001) ideas which group knowledge of vacabulary into productive and receptive knowledge.

To define productive competence or knowledge of collocation, Alsakran (2011) says "Productive knowledge is the ability to use and have access to words (i.e. collocations) in speech and writing" (p. 11). Productive knowledge is then closely related to speaking and writing, two language skills which are also productive. In other words, learners have the productive knowledge of collocation if they realize while speaking or writing that the item homework as a node or cluster, for 
example, should be paired with do (or its other inflections) as its collocate. Learners' mistakes in the choice of inflections and in spelling do not deny that they have the knowledge (see Brashi 2006, p. 27).

Receptive knowledge of collocation, on the other hand, is a language skill of EFL/ESL learners in which they just recognize collocation and its meaning only when they read it in a text or listen to it being spoken (Brashi, 2006). In other words, receptive knowledge just enables learners to recognize that a certain collocate can be combined with a certain node or cluster, not with another cluster to form an acceptable collocation, when they are exposed to the use of the collocation. As such, receptive knowledge of collocation is passive since learners may not be able to apply the knowledge in their speaking and writing skills.

\section{METHOD}

\section{Participants}

The study was conducted in the English Language Department, Bandung State Polytechnic. A total of 49 students (two classes) participated in the study. There were 11 males and 38 females in the sample with the ages ranging from 19 to 21 years old. They had been in the English Language Department for nearly two years, studying various English subjects such as the four main English skills (Listening, Speaking, Reading and Writing). Besides, they had taken other subjects that included Grammar, Vocabulary, English for Business, and Translation. As such, their English proficiency level was safely assumed to be at Intermediate. This is the English proficiency level targeted officially by the English Language Department for its graduates to achieve at the very least. Therefore, the participants of this study, though still in the process of finishing their studies, could be considered to represent graduates of the English Language Department formally.

\section{Research Method and Design}

The research was conducted by adopting qualitative method. The method was used in order that in-depth analyses of the students' levels of productive and receptive knowledge of collocation were to be done. According to Sugiyono (2010), research using the method is also called an interpretative study. In the kind of study, it is said that researchers "can do no more than interpret" since reality contains mysteries to which they must submit (Holliday, 2007, p. 6). It is believed that knowledge and meaning are the results of interpretation. In this study, therefore, data found were interpreted to address the aims of the study. Those are to reveal the learners' levels of productive and receptive knowledge of $\mathrm{v}+\mathrm{n}$ and $\operatorname{adj}+n$ collocations and to show which one of these two types of collocational knowledge or competence is more problematic for the learners.
To address its aims, the research was designed as a case study. Creswell (2007) defined case study research as a qualitative approach in which the investigator explores a bounded system (a case), or multiple bounded systems (cases) over time through detailed, in-depth data collection involving multiple sources of information such as documents or texts and interviews. The sources of information in this study were the formations of collocation the participants made productively and receptively when they took Test 1 and Test 2. One possible weakness of the design was that its findings might not be generalized since the findings were unique, reflecting certain phenomena in one particular setting.

\section{Instruments of Data Collection}

Two instruments, a blank-filling test of productive knowledge of collocation (Test 1) and a multiple choice test of receptive knowledge of collocation (Test 2), were used to collect the required data to reveal the participants' levels of productive and receptive knowledge of $\mathrm{v}+\mathrm{n}$ and adj+n collocations. The same instruments were also utilized to show whether $v+n$ collocation or adj $+n$ collocation was more problematic for the participants. The models of the two instruments (Test 1 and Test 2) can be seen in Appendix 1 and 2.

The first instrument, Test 1 , consisted of 40 sentences with a blank in each to be filled by the participants. Of the 40 sentences, 20 were to be filled with an appropriate verb and the other 20 with a suitable adjective to be paired with a noun to form $\mathrm{v}+\mathrm{n}$ and $\mathrm{adj}+\mathrm{n}$ collocations. It is said that besides a translation test, a blank filling test is common to be administered to measure learners' level of productive collocational competence (Mahvelati \& Mukundan, 2012). In designing the test instrument, two models were consulted, one created by Brashi (2006) and the other by Koya (2003), though the two models were for assessing the level of productive knowledge of $\mathrm{v}+\mathrm{n}$ collocation only. Oxford Collocations Dictionary (McIntosh, 2009) and online text sources such as British National Corpus (BNC) were also referred to in designing the test instrument. Further, the level of language difficulty of the sentences in the test was suited in accordance to the participants' level of English proficiency, namely Intermediate.

The second instrument was multiple choice test (Test 2). It is said that multiple-choice test type is commonly used to assess the learners' level of receptive knowledge of collocation (Mahvelati \& Mukundan, 2012). The process of designing the test instrument (Test 2) was practically the same with that of designing Test 1 mentioned above, except in one respect. Unlike in Test 1, in Test 2 the answer choices (choices of verbs and nouns) were provided to complete the sentences in it. In brief, the 
participants did not need to find themselves the suitable verbs and adjectives.

\section{Test Procedures}

The researchers first of all contacted the head of English Language Department of Bandung State Polytechnic, telling the purpose to conduct this study. After the permission was obtained, the researchers prepared 49 copies of Test 1 and Test 2 for the participants to take. On the following day, we visited their class, explained them about the research and asked for their help to participate. The researchers also assured them that the scores (within a continuum ranging from 0 to 100) of the tests would not be publicized and have no effects on their academic scores. In other words, their confidentiality were guaranteed.

The two tests were taken by the participants in succession. To consider the total number of problems of sentences to complete (just 40 for each test), the first test instrument was administered for 35 minutes, while the second one for 25 minutes. Test 1 took more time since the participants had to find themselves the required collocates (a verb or an adjective) to fill the blank in each sentence. No special treatment, for example explanation or teaching of collocation to boost their scores, was given to the participants' before the tests were taken.

\section{RESULTS AND DISCUSSION}

This part discusses the participants' rensponses to Test 1 and Test 2. To judge whether the responses were accurate or not, they were checked against three references. They are Oxford Collocations Dictionary (McIntosh, 2009), British National Corpus (BNC), an online text source, and an online collocation checker (http://candle.cs.nthu.edu.tw/vntango/). The responses produced were considered to be wellformed when they matched samples of collocation mentioned in one of the references above. Problems with spelling or grammar in the responses did not cause the collocations formed by the 49 participants to be malformed.

Data from Test 1 as displayed in Tabel 1 show an overall moderate knowledge/ competence in producing well-formed verb+noun and $\mathrm{adj}+\mathrm{n}$ collocations in English.

Tabel 1 Results of the blank-filling test (Test 1 ) of productive competence in $v+n \&$ adj $+n$ collocations

\begin{tabular}{crrrr}
\hline \multirow{2}{*}{ Item no. } & \multicolumn{2}{c}{ v+n collocation } & \multicolumn{2}{c}{ adj+n collocation } \\
\cline { 2 - 5 } & well-formed & malformed & well-formed & malformed \\
\hline 1 & $26 / 53 \%$ & $23 / 47 \%$ & $36 / 73.4 \%$ & $13 / 26.6 \%$ \\
\hline 2 & $37 / 75.5 \%$ & $12 / 24.5 \%$ & $26 / 53 \%$ & $23 / 47 \%$ \\
\hline 3 & $47 / 95.9 \%$ & $2 / 4.1 \%$ & $43 / 87.7 \%$ & $6 / 12.3 \%$ \\
\hline 4 & $18 / 36.7 \%$ & $31 / 63.3 \%$ & $26 / 53 \%$ & $23 / 47 \%$ \\
\hline 5 & $43 / 87.7 \%$ & $6 / 12.3 \%$ & $16 / 32.6 \%$ & $32,3 / 67.4 \%$ \\
\hline 6 & $15 / 30.6 \%$ & $34 / 69.4 \%$ & $44 / 89.8 \%$ & $5 / 10.2 \%$ \\
\hline 7 & $41 / 83.6 \%$ & $8 / 16.4 \%$ & $32 / 65.3 \%$ & $17 / 34.7 \%$ \\
\hline 8 & $42 / 85.7 \%$ & $7 / 14.3 \%$ & $20 / 40.8 \%$ & $29 / 59.2 \%$ \\
\hline 9 & $44 / 89.8 \%$ & $5 / 10.2 \%$ & $20 / 40.8 \%$ & $29 / 59.2 \%$ \\
\hline 10 & $38 / 77.4 \%$ & $11 / 22.6 \%$ & $43 / 87.7 \%$ & $6 / 12.3 \%$ \\
\hline 11 & $14 / 28.6 \%$ & $35 / 71.4 \%$ & $30 / 61.2 \%$ & $19 / 38.8 \%$ \\
\hline 12 & $26 / 53 \%$ & $23 / 47 \%$ & $40 / 81.6 \%$ & $9 / 18.4 \%$ \\
\hline 13 & $20 / 40.8 \%$ & $29 / 59.2 \%$ & $18 / 36.7 \%$ & $31 / 63.3 \%$ \\
\hline 14 & $40 / 81.5 \%$ & $9 / 18.5 \%$ & $45 / 91.8 \%$ & $4 / 8.2 \%$ \\
\hline 15 & $28 / 57 \%$ & $21 / 43 \%$ & $6 / 12.2 \%$ & $43 / 87.8 \%$ \\
\hline 16 & $37 / 75.5 \%$ & $12 / 24.5 \%$ & $39 / 79.6 \%$ & $10 / 20.4 \%$ \\
\hline 17 & $49 / 100 \%$ & $0 / 0 \%$ & $17 / 34.7 \%$ & $32 / 65.3 \%$ \\
\hline 18 & $37 / 75.5 \%$ & $12 / 24.5 \%$ & $10 / 20.4 \%$ & $39 / 79.6 \%$ \\
\hline 19 & $15 / 30.6 \%$ & $34 / 69.4 \%$ & $43 / 87.7 \%$ & $6 / 12.3 \%$ \\
\hline 20 & $41 / 83.6 \%$ & $8 / 16.4 \%$ & $10 / 20.4 \%$ & $39 / 79.6 \%$ \\
\hline Average & $\mathbf{3 3 / 6 7 \%}$ & $\mathbf{1 6 / 3 3 \%}$ & $\mathbf{2 8 / 5 7 . 2 \%}$ & $\mathbf{2 1 / 4 2 . 8 \%}$ \\
\hline & Scores \% productive competence in v+n and adj+n collocations: $(67+57.2): 2=\mathbf{6 2 . 1}$ \\
\hline
\end{tabular}

As seen in the last row, the participants' scores of productive competence in these two types of collocation stand at 62.1. The results suggest that 62.1 percent of their responses (supplies of verbs and adjectives) were correct, while only 37.9 per cent were incorrect. The results come as a surprise since some researchers (Al-Zahrani, 1998; Brashi, 2006; Liu, 1999; Nesselhauf, 2003) have indicated learners' difficulties in producing acceptable collocations. Brashi (2006) specifically reveals that only $38 \%$ of collocations can be produced appropriately by EFL learners. The 49 participants of this study, therefore, performed much better than their counterparts, 20 undergraduate students that became the subjects of Brashi's research.

The better performance of the participants of this study might result from the moderate level of the test difficulty. The participants, for example, were asked to supply suitable collocates (e.g. verbs) to be paired with common nodes or clusters such as mistakes, homework and test (see Appendix 1 for more information). By contrast, in Brashi's model of 
test, the participants were required to seek themselves for collocates to be combined with clusters such as a pact, a civil war, rage and caution, which are relatively more difficult.

Another reason for the better performance of the study's participants was related to the participants' relatively fair degree of collocational awareness. It was found out that they had been introduced to the concept of collocation through several courses. Not to mention from grammar courses, from vocabulary courses they gained the concept since they used a textbook for learning vocabulary informed by Lewis' (1993) The Lexical Approach. The approach is known to put lexical phrases (e.g. collocation) in a central position in the process of teaching and learning. In writing courses, teacher's indirect feedback on the participants' writing was revealed to include how to pair words naturally to form acceptable collocations.

To turn discussions to the data from Test 2 (the multiple-choice test) as presented in Table 2, the data show the participants' average scores of receptive competence or knowledge of $\mathrm{v}+\mathrm{n}$ and $\operatorname{adj}+n$ collocations. The scores are better than the participants' productive competence in verb + noun and adj $+\mathrm{n}$ collocations. It suggests that around $80.7 \%$ of the participants' responses were correct, while only $19.3 \%$ were incorrect. These data are displayed in the last row of Table 2. The scores revealed by this study are virtually the same as the scores reported by Brashi (2006), who suggested that the participants of his research scored 79 in the multiple choice test of receptive knowledge of collocation.

Tabel 2. Results of the multiple choice test (Test 2) of receptive competence in $v+n \&$ adj+n collocations

\begin{tabular}{crrrr}
\hline \multirow{2}{*}{ Item no. } & \multicolumn{2}{c}{ v+ n collocation } & \multicolumn{2}{c}{ adj+n collocation } \\
\cline { 2 - 5 } & well-formed & malformed & well-formed & malformed \\
\hline 1 & $48 / 98 \%$ & $1 / 2 \%$ & $47 / 96 \%$ & $2 / 4 \%$ \\
\hline 2 & $42 / 85.7 \%$ & $7 / 14.3 \%$ & $44 / 89.8 \%$ & $5 / 10.2 \%$ \\
\hline 3 & $47 / 96 \%$ & $2 / 4 \%$ & $33 / 67.3 \%$ & $16 / 32.7 \%$ \\
\hline 4 & $24 / 49 \%$ & $25 / 51 \%$ & $41 / 83.7 \%$ & $8 / 16.3 \%$ \\
\hline 5 & $49 / 100 \%$ & $0 / 0 \%$ & $46 / 94 \%$ & $3 / 6 \%$ \\
\hline 6 & $35 / 71.4 \%$ & $14 / 28.6 \%$ & $48 / 98 \%$ & $1 / 2 \%$ \\
\hline 7 & $41 / 83.7 \%$ & $8 / 16.3 \%$ & $40 / 81.6 \%$ & $9 / 18.4 \%$ \\
\hline 8 & $48 / 98 \%$ & $1 / 2 \%$ & $41 / 83.7 \%$ & $8 / 16.3 \%$ \\
\hline 9 & $49 / 100 \%$ & $0 / 0 \%$ & $36 / 73.5 \%$ & $13 / 26.5 \%$ \\
\hline 10 & $45 / 91.8 \%$ & $4 / 8.2 \%$ & $32 / 65.3 \%$ & $17 / 34.7 \%$ \\
\hline 11 & $47 / 96 \%$ & $2 / 4 \%$ & $41 / 83.7 \%$ & $8 / 16.3 \%$ \\
\hline 12 & $35 / 71.4 \%$ & $14 / 28.6 \%$ & $47 / 96 \%$ & $2 / 4 \%$ \\
\hline 13 & $39 / 79.6 \%$ & $10 / 20.4 \%$ & $35 / 71.4 \%$ & $14 / 28.6 \%$ \\
\hline 14 & $41 / 83.7 \%$ & $8 / 16.3 \%$ & $44 / 89.8 \%$ & $5 / 10.2 \%$ \\
\hline 15 & $44 / 89.8 \%$ & $5 / 10.2 \%$ & $17 / 34.7 \%$ & $32 / 65.3 \%$ \\
\hline 16 & $48 / 98 \%$ & $1 / 2 \%$ & $41 / 83.7 \%$ & $8 / 16.3 \%$ \\
\hline 17 & $48 / 98 \%$ & $1 / 2 \%$ & $20 / 41 \%$ & $29 / 59 \%$ \\
\hline 18 & $27 / 55.1 \%$ & $22 / 44.9 \%$ & $8 / 16.3 \%$ & $41 / 83.7 \%$ \\
\hline 19 & $43 / 87.7 \%$ & $6 / 12.3 \%$ & $48 / 98 \%$ & $1 / 2 \%$ \\
\hline 20 & $40 / 81.6 \%$ & $9 / 18.4 \%$ & $26 / 53 \%$ & $23 / 47 \%$ \\
\hline Average & $\mathbf{4 2 / 8 6 \%}$ & $\mathbf{7 / 1 4 \%}$ & $\mathbf{3 7 / 7 5 . 5 \%}$ & $\mathbf{1 2 / 2 4 . 5 \%}$ \\
\hline & Scores of receptive competence of v+n and adj+n collocations: $(86+75.5): 2=\mathbf{8 0 . 7}$ \\
\hline
\end{tabular}

In sum, the data show that EFL/ESL learners may have a receptive knowledge of a wide range of collocations. They can recognise well-formed L2 collocations and their meanings when they read and listen. To put it differently, they generally have broad knowledge of collocation as part of their listening and reading skills. On the other hand, in their productive skills (speaking and writing), their ability to use a wide range of collocations could be lower. These findings about the learners' productive and receptive knowledge of collocation are similar to what has been reported by some linguists (Brashi, 2006; Hill, 2000; Koya 2003). The ability to use collocations productively is, however, not as lower as that reported in Brashi's (2006) research. The learners' productive knowledge of collocation then needs more attention than their receptive knowledge of collocation. In other words, it is the learners' ability to use collocations appropriately in writing and speaking, not their understanding of the meanings of collocations, that is more important.

Further, the surprising data reported by this research are linked to which type of collocation is more problematic for EFL learners. The research suggested that adj $+n$ collocation was more difficult both productively and receptively than $v+n$ collocation. As shown in the last rows of Table 1 and Table 2, the participants' scores of productive (67) and receptive competence (86) in $v+n$ collocation are higher than those of productive (57.2) and receptive competence (75.5) in adj+n collocation. The finding is conflicting with the result of a study conducted by Kuo (2009), who claimed " $v+n$ collocation is more difficult than adj $+n$ collocation" (p. 148). As the finding suggests that the learners make more mistakes in $\operatorname{adj}+\mathrm{n}$ than $\mathrm{v}+\mathrm{n}$ 
collocation, it also seems to be contrary to the common belief that has been widely held that mistakes in $v+n$ collocation are typical in EFL learners' production (Al-Zahrani, 1998; Nesselhauf, 2003; Sun, 2004) and that mistakes in $v+n$ collocation $(50 \%)$ are more than those in adj+n collocation, which amount to $25 \%$ (Siyanova \& Schmitt, 2008; Yan, 2010).

To account for the surprising finding posited by this research, it seems to be rooted in the type of instrument used in the research: tests (not texts written by participants). In the tests, the participants were asked to produce or choose adjectives they thought appropriate to fit the contexts of sentences even though they did not know for sure whether the adjectives were correct or not. This way, they were then forced to demonstrate their real knowledge of $\operatorname{adj}+n$ collocation. As shown in this research, it turned out that the participants' factual knowledge or competence in $\operatorname{adj}+n$ collocation was lower than their competence in $\mathrm{v}+\mathrm{n}$ collocation.

By contrast, the application of written texts as an instrument in other research was likely not to reflect the participants' factual collocational knowledge or competence. It is known that the uses of adjectives are optional in English language. For this reason, the participants tended to use few adjectives in their writing, limited to the ones the usage of which they knew for sure. In other words, the participants could avoid using adjectives, alone or with other words - thus hide their true knowledge of $\operatorname{adj}+n$ collocation in their writing. Therefore, learners' fewer mistakes in $\operatorname{adj}+n$ than in $v+n$ collocation found in their writing does not mean that they had high competence in $\operatorname{adj}+n$ collocation, or higher competence in this type of collocation than in $\mathrm{v}+\mathrm{n}$ collocation. Rather, that was due to their fewer uses of adj $+n$ collocation than their uses of $v+n$ collocation in the first place.

\section{CONCLUSIONS AND SUGGESTIONS}

The division of collocational competence into productive and receptive type is important. One advantage to see collocational competence this way is that EFL learners' factual level of collocational knowledge can be measured more precisely. Another advantage is that EFL learners' problems of understanding collocation, especially of using it, will likely be better handled. That is so since it is productive competence in collocation that is more important to them. Therefore, teaching practitioners can draw the learners' attention more to this type of collocational competence by designing effective instructions of teaching it.

Compared with receptive competence, productive competence of collocation is more problematic for EFL learners. This comes as no surprise since productive competence is based on explicit knowledge of collocation that a certain word can be combined with one particular word but cannot with another word. By contrast, receptive knowledge of collocation is just an ability to recognize two words often co-occur as collocation when they are heard or read. The knowledge or competence does not need a collocational awareness on the part of the learners - an awareness that enables them to produce well-formed collocations.

In this research, it is revealed that the participants' scores of productive competence are lower than their scores of receptive competence. This means that though receptive competence is important, productive competence is more important. Hence, productive competence needs to be learned and understood more by EFL learners because the competence is closely related to the learners' productive skills: speaking and writing. It is more urgent that EFL learners' attention is drawn to this productive competence or knowledge of collocation in order to learn it more successfully.

Further, research on collocation should not be limited to focus on the type of $v+n$ only. Other types are required to be investigated too, especially adj $+n$ collocation. It is true that $\mathrm{v}+\mathrm{n}$ collocation is mistakenly realized more than adj $+n$ collocation in EFL learners' writing. However, their real or factual knowledge of adj $+n$ collocation is more limited than that of $v+n$ collocation as evidenced in this research. To put it differently, adj $+n$ collocation is actually more problematic than $v+n$ collocation for the learners. Therefore, it is time the same amount of if not more - attention is paid to the teaching and learning of adj $+n$ collocation to help them with their productive and receptive English language skills. Otherwise, it is quite likely that a phenomenon called "lexical teddy bears" (Hasselgren 1994 in Laufer \& Waldman, 2011) will arise. In this phenomenon, EFL/ESL learners keep using a limited number of adjectives as a result of their low ability in using adjectives regardless of their socalled advanced level of English proficiency. They combine the adjectives with various words and nouns, and end up forming awkward combinations and malformed collocations.

\section{REFERENCES}

Alsakran, R.A. (2011). The productive and receptive knowledge of collocations by Advanced Arabic-speaking ESL/EFL learners. Unpublished Thesis, Colorado State University, Fort Collins, Colorado.

Al-Zahrani, M. S. (1998). Knowledge of English lexical collocations among male Saudi college students majoring in English at Saudi University. Unpublished doctoral dissertation, Indiana University of Pennsylvania, Pennsylvania, USA.

Anari, S. M. \& Ghaffarof, S. (2013). The effect of collocational competence on translation 
accuracy of translation trainees. Journal of Advances in English Language Teaching, Vol. 1, No. 3, pp 76-84.

Bahns, J. \& Eldaw, M. (1993). Should we teach EFL students collocation? System, 21(1), 104114. http://dx.doi.org/10.1016/0346251X(93)90010-E

Bazzaz, F. E. \& Samad, A.A. (2011). The use of verb-noun collocations in writing stories among Iranian EFL learners. English Language Teaching 4. 3 (Sep 2011): 158-163.

Benson, M., Benson, E. \& Ilson, R. (1997). The BBI dictionary of English word combinations $\left(2^{\text {nd }}\right.$ edition). Amsterdam, The Netherlands: John Benjamins Publishing Company.

Bonk, W.J. (2000). Testing ESL learners' knowledge of collocations. (ERIC Document Reproduction Service No. ED 442 309).

Brashi, A. (2006). Collocability as a problem in L2 production. Reflections on English Language Teaching, Vol 8, No 1, pp. 12-34.

Creswell, J.W. (2007). Qualitative inquiry \& reseach design: Coosing among five approaches $\left(2^{\text {nd }} \mathrm{Ed}\right)$. Thousand Oaks, California: Sage Publication.

Eggins, S. (2004). An Introduction to Systemic Functional Linguistics. London: Continuum International Publishing Group.

Ellis, N.C. (2001). Memory for language. In P. Robinson (Ed.), Cognition and second language instructions (pp. 33-68). Cambridge: Cambride University Press.

Firth, J. R. (1957). Papers in linguistics 1934-1951 pp. 177-189.

Halliday, M.A.K. and Hasan, R. (1976). Cohesion in English. London: Longman.

Halliday, M. A. K. and Hasan, R. (1985). Language, Context, and Text: Aspect of Language in a Social-Semiotic Perspective. Victoria 3217: Deakin University Press.

Halliday, M.A.K. and Matthiessen, C.M.I.M. (2004). An Introduction to Functional Grammar 3rd Ed. Great Britain: Oxford University Press Inc.

Henriksen B. (2013). Research on L2 learners' collocational competence and development $-a$ progress report.

http://www.eurosla.org/monographs/ EM02/Henriksen.pdf

Hasselgren, A. (1994). Lexical teddy bears and advanced learners: A study into the ways Norwegian students cope with English vocabulary. International Journal of Applied Linguistics, 1994.

Hill, J. (2000). Revising priorities: From grammatical failure to collocational success. In M. Lewis (ed.), Teaching collocation: Further developments in the lexical approach (pp. 4769). Hove: Language Teaching Publications.
Holliday, A. (2007). Doing and Writing Qualitative Research $2^{\text {nd }} E d$. Thousand Oaks California: Sage Publications Ltd.

Howarth, P. (1998). Phraseology and second language proficiency. Applied Linguistics, 19 (1), 24-44.

Hsu, J. (2007). Lexical collocations and their relations to the online writing of Taiwanese college English majors and non-English majors. Electronic Journal of Foreign Language Teaching, 4 (2), 192-209.

Koya, T. (2003). A Study of Collocation in English and Japanese Noun-Verb Combinations. Intercultural Communication Studies XII-I 2003.

www.uri.edu/iaics/content/2003v12n1/08\%20 Taeko\%20Koya.pdf

Kuo, C. L. (2009). An analysis of the use of collocation by intermediate EFL college students in Taiwan. ARECLS, 2009, vol.6, 141155.

Laufer, B., \& Waldman, T. (2011). Verb-noun collocations in second language writing: A corpus analysis of learners' English. Language Learning 61 (2) June 2011, pp. 647-672.

Lewis, M. (1993). The lexical approach. London: Language Teaching Publications.

Lewis, M. (2000). Language in the lexical approach. In M. Lewis (ed.), Teaching collocation: Further developments in the lexical approach (pp. 10-27). London: Language Teaching Publications.

Liu, C-P. (1999). An analysis of collocational errors in EFL writings. In The Proceedings of the Eighth International Symposium on English Teaching (pp. 483-494). Taipei, Taiwan: Crane Bookstore.

Mahvelati, E. H. \& Mukundan, J. (2012). The role of cognitive style in the collocational knowledge development of Iranian EFL learners through input flood treatment. English Language Teaching 5. 10 (2012): $105-$ 117.

Martin, J.R. (1992). English Text: System and Structure. Amsterdam: John Benjamin's Publishing Company.

McArthur, T. (1992). The Oxford companion to the English language. Oxford: Oxford University Press.

McCarthy, M. (1990). Vocabulary. Oxford: Oxford University Press.

McIntosh, C. (2009). Oxford collocations dictionary for students of English $3^{\text {rd }}$ Ed. Oxford New York: Oxford University Press.

Miyakoshi, T. (2009). Investigating ESL learners' lexical collocations: The acquisition of verb+noun collocations by Japanese learners of English.

www.ling.hawaii.edu/graduate/dissertations/To moko MiyakoshiFinal.pdf 
Nation, I.S.P. (2001). Learning vocabulary in another language. Cambridge: Cambridge University Press.

Nesselhauf, N. (2003). The use of collocation by advanced learners of English and some implications for teaching. Applied Linguistics, 24(2), 223-242.

Palmer, H.E. (1933). Second interim report on English collocations. Tokyo: Kaitakusha.

Saudin, H. (2014). The realization of collocation in EFL students' written texts across three proficiency levels. In the Proceedings of the $61^{\text {st }}$ TEFLIN International Conference. Book 1 pp. 367-370.

Sugiyono (2010). Metode penelitian kuantitatif, kualitatif dan $R$ dan D. Bandung: Alfabeta.

Sun, C. Y., (2004). An analysis of lexical collocation errors in the English paragraph writing of Senior High School EFL students in Taiwan. Unpublished master thesis, University of Newcastle Upon Tyne, UK.

Sung, J. (2003). English lexical collocations and their relation to spoken fluency of adult nonnative speakers. Unpublished doctoral dissertation, Indiana University of Pensylvania, Pensylvania, USA.

Siyanova, A., \& Schmitt, N. (2008). L2 learner production and processing of collocation: A multi-study perspective. The Canadian Modern Language Review, 64(3), 429-458.

Taboada, M. (2004). Building Coherence and Cohesion: Task-oriented Dialogue in English and Spanish. Philadelphia/Amsterdam: John Benjamins Publishing.

Yan, H. (2010). Study on the causes and countermeasures of the lexical collocation mistakes in College English. English Language Teaching. March 2010: 162-165. http://search.proquest.com/docview/83975576 2 ? accountid=13567

Zhang, X. (1993). English collocations and their effect on the writing of native and non-native college freshmen. Indiana University of Pennsylvania: Pennsylvania.

Zughoul, M.R., \& Abdul-Fattah, H. (2003). Collocational strategies of Arab learners of English: A study in lexical semantics. (ERIC Document Reproduction Service No. ED 479746). 


\section{APPENDIX 1}

Test 1: Blank-filling test of Productive Collocation Knowledge

A. Fill each blank in the following sentences with the most suitable verb that best collocates with the noun (in italics).

1. In order to .... time, Susan took a taxi to go to her campus.

2. I .... several mistakes in the test.

3. Most students complained because they had to .... a lot of homework.

4. Don't go outside. It's chilly. If you do, you will .... a cold.

5. If you just talk and don't .... attention to the road, we 'll have an accident.

6. From all we have discussed so far in this meeting, can you .... some conclusions?

7. After considering some countries to visit, she decided to .... a vacation to Italy.

8. We were told not to .... noise because other students were taking exams.

9. .... this secret. Don't tell it to the third party or anyone else.

10. How often should I .... this medicine a day?

11. Kate .... the entrance examination for the university, so now she is a university student.

12. Why do you .... business with that firm? The firm is not a good one.

13. He ran from the house saying that he was going to .... suicide.

14. Never .... your promise. Once you do it, nobody will trust you anymore.

15. Now, Ann is popular among her friends because she .... a speech contest just last month.

16. If you .... the law, you will certainly be arrested.

17. I am hungry; everybody is hungry. What time will we .... lunch?

18. Would you like to .... a job in an insurance company or a bank?

19. What time does the hotel usually .... breakfast in the morning for its guests?

20. To solve some company's problems, they will .... a meeting next week.

B. Fill each blank in the following sentences with the most suitable adjective that best collocates with the noun (in italics)

1. It is a story with a/an .... ending and a new beginning.

2. Her manner is often fierce. Yet, she has a .... heart.

3. Because it was such a .... day, she couldn't sunbathe.

4. He smokes more than two packs of cigarettes a day. He is a .... smoker.

5. The car has a .... machine so it certainly will win the race.

6. Can we stop here for a meal? The restaurant offers a variety of .... foods.

7. Although English is not my.... language, I've lived and worked in Britain for many years.

8. The doctor ordered him to take .... exercise to lose weight"

9. The .... wind made the trees sway wildly; some even felled down to the ground.

10. My company has a .... reputation as a company which provides excellent after-sales services.

11. He won't be able to lift such a .... suitcase. He's only nine years old.

12. A death sentence for a drug dealer has been a .... news topic recently.

13. During rush hours, the traffics are extremely.... on that road.

14. The train is very ..... It travels more than $200 \mathrm{~km}$ an hour.

15. Young people nowadays like listening more to .... music than to soft music.

16. The mall offers a .... discount next week in its grand opening.

17. Living in an apartment in a big city demands a/an .... cost that not every family can afford.

18. The area where I live is considered to have .... population because many people live there.

19. The rain was .... so that floods happened in some areas.

20. Can I have some .... change? I need it to make a telephone call. 


\section{APPENDIX 2}

Test 2: The Multiple-Choice Test of Receptive Collocation Knowledge

A. Choose the verb that best collocates with the noun (in italics) in the following sentences.

1. In order to .... time, Susan took a taxi to go to her campus.

2. I .... several mistakes in the test.
A. economize
B. keep
C. save
A. made
B. did
C. put

3. Most students complained because they had to .... a lot of homework almost every day.
A. make
B. do
C. have

4. Don't go outside. It's chilly. If you do, you will .... a cold.
A. get
B. catch
C. take

5. If you just talk and don't ..... attention to the road, we 'll have an accident.
A. give
B. pay
C. take

6. From all we have discussed so far in this meeting, can you .... some conclusions?
A. draw
B make
C. do

7. After considering some countries to visit, she decided to .... a vacation to Italy.
A. go
B. catch
C. take

8. We were told not to .... noise because other students were taking exams.
A. produce
B. make C. do

9. .... this secret. Don't tell it to Don't tell it to the third party or anyone else.

10. How often should I .... this medicine a day?
A. protect
B. keep C. guard
A. drink
B. take C. eat

11. Kate .... the entrance examination for the university, so now she is a university student.

A. pass B. make C. hit

12. Why do you .... business with that firm?
A. do
B. make
C. go

13. He ran from the house saying that he was going to .... suicide.
A. do
B. conduct
C. commit

14. Never .... your promise. Once you do it, nobody will trust you anymore.
A. spoil
B. violate
C. break

15. Now, Ann is popular among her friends because she .... a speech contest just last month.

16. If you .... the law, you will certainly be arrested.
A. won
B. overcame
C. succeeded

$\begin{array}{lll}\text { A. oppose } & \text { B. break } & \text { C. contradict }\end{array}$

17. I am hungry; everybody is hungry. What time will we .... lunch?
A. have
B. get
C. take

18. Would you like to .... a job in an insurance company or a bank?
A. receive
B. obtain
C. get

19. What time does the hotel usually .... breakfast in the morning for its guests?
A. give
B. serve C. prepare

20. To solve some company's problems, they will .... a meeting next week.
A. arrange
B. schedule
C. programme

B. Choose the adjective that best collocates with the noun (in italics) in the following sentences.

1. It is a story with $\mathrm{a} / \mathrm{an}$.... ending and a new beginning.
A. merry
B. happy
C. good

2. Her manner is often fierce. Yet, she has a .... heart.
A. nice
B. kind
C. friendly

3. Because it was such a .... day, she couldn't sunbathe.
B. hot
B. bright
C. clear

4. He smokes more than two packs of cigarettes a day. He is a .... smoker.
A. strong
B. heavyC. hard

5. The car has a .... machine so it certainly will win the race.
A. strong
B. powerful
C. forceful

6. Can we stop here for a meal? The restaurant offers a variety of .... foods.
A. delicious
B. nice
C. pleasant 
7. Although English is not my .... language, I've lived and worked in Britain for many years.
A. original
B. parent
C. native

8. The doctor ordered him to take .... exercise to lose weight"
A. heavy
B. repeated
C. regular

9. The .... wind made the trees sway wildly; some even felled down to the ground.
A. forceful
B. strong
C. heavy

10. My company has a .... reputation as a company which provides excellent after-sales services.
A. huge
B. large
C. big

11. He won't be able to lift such a .... suitcase. He's only nine years old.
A. heavy
B. packed
C. weighty

12. A death sentence for a drug dealer has been a .... news topic recently.
A. hot
B. warm
C. favourite

13. During rush hours, the traffics are extremely.... on that road.
A. A. full
B. busy C. many

14. The train is very ..... It travels more than $200 \mathrm{~km}$ an hour.
A. quickB. speedy
C. fast

15. Young people nowadays like listening more to .... music than to soft music.
A. loud
B. hard
C. noisy

16. The mall offers a .... discount next week in its grand opening.
A. huge
B. large
C. big

17. Living in an apartment in a big city demands a/an ... cost that not every family can afford.
A. expensive
B. high
C. big

18. The area where I live is considered to have .... population because many people live there.
A. big
B. dense
C. crowded

19. The rain was .... so that floods happened in some areas.
A. heavy B. hard
C. huge

20. Can I have some .... change? I need it to make a telephone call.
A. small
B. little
C. low 